\title{
AC 2007-502: USING THE SENIOR DESIGN JURY TO DIRECTLY ASSESS PROGRAM OUTCOMES
}

\section{Michael Bronzini, George Mason University}

Michael S. Bronzini currently holds the Dewberry Chair in Civil, Environmental, and Infrastructure Engineering (CEIE) in the Volgenau School of Information Technology and Engineering at George Mason University in Fairfax, Virginia, and is also the Chair of the CEIE Department. Prior positions include Director of the Center for Transportation Analysis at Oak Ridge National Laboratory, Chair of the Department of Civil Engineering at Penn State University, and Director of the Transportation Center and Professor of Civil Engineering at the University of Tennessee. Dr. Bronzini holds the M.S. and Ph.D. degrees from Penn State and a B.S. degree from Stanford University, all in Civil Engineering. He has 40 years of experience in transportation and civil engineering research, teaching, and consulting, and is a registered Professional Engineer. He is a member of ASEE and ASCE, has been an ABET civil engineering program evaluator for many years, and is a National Associate of the National Academies.

\section{John Matusik, The Engineering Groupe}

John Matusik, PE is an Adjunct Professor in the Department of Civil, Environmental, and Infrastructure Engineering at George Mason University in Fairfax, Virginia, and in 2003 was recognized as the Outstanding Adjunct Professor in the Volgenau School of Information Technology and Engineering. John holds a B.S. degree in Civil Engineering and an M.S. degree in Water Resources from George Washington University. He is a Registered Professional with more than 24 years of experience in civil engineering, surveying and water resources. John is a member of the Virginia Floodplain Managers Association (VFMA), Association of State Dam Safety Officials (ASDSO), American Water Resources Association (AWRA) and American Society of Civil Engineers (ASCE). John served as coordinating editor and co-author for the Land Development Handbook, published in 1996 by McGraw Hill. He has been the principal instructor for the senior design course in Civil and Infrastructure Engineering at Mason for the past decade. 


\title{
Using the Senior Design Jury to Directly Assess Program Outcomes
}

\begin{abstract}
The senior design project course that is required for the B.S. degree in civil and infrastructure engineering at George Mason University is built around teams of students completing land design projects. Final projects are presented in a public forum, and various aspects of student performance are graded by a design jury. This paper describes the methods used for this senior design course, presents the assessment process, and shows how the results are used to measure student performance on the traditional ABET a-k outcomes. Results achieved over the past several years and the ensuing program changes are summarized.
\end{abstract}

\section{Senior Design Course Requirements and Procedures}

The basic premise of the course is that each student team will prepare the preliminary layout and design for a land development project. The lead instructor for the course and co-author of this paper is a practicing land development engineer, and the support instructor is a practicing structural engineer. Departmental faculty or local land design practitioners play the role of the project clients. Each team takes an assigned actual land parcel in a nearby jurisdiction and, for a specified residential, commercial, or industrial project, prepares preliminary designs for the layout, street system, grading, drainage, water supply and wastewater systems, and all connections to the relevant offsite systems. A portion of the proposed project is selected for a preliminary structural design. The students also develop construction cost estimates, and perform a traffic impact study.

Student teams typically have five to seven members. To ensure that all students participate, both individual and group work products are required (see below). All students must also participate in the final presentation. In addition, each team member evaluates the contribution of the other members, and those evaluations are considered by the instructor in determining final grades.

The land parcel used and the design specifications for each team change with each offering of the course. Portions of the specific instructions to the students for Spring 2006 are given below.

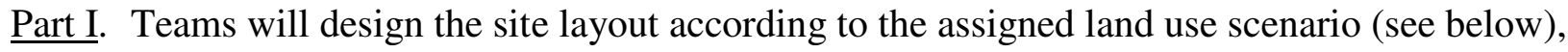
subject to acceptance by the client. Upon acceptance by the client (i.e., notice to proceed), the teams will then perform the engineering tasks for final layout and design of: (a) water supply and distribution system; (b) wastewater collection system; (c) stormwater management and storm drainage system; (d) the transportation system; (e) erosion and sediment control; and (f) structural design for an assigned project component. One industry mentor will be available on a limited basis to each group, and the departmental faculty will also provide guidance upon request.

Part II. Develop the design documents (drawings and computations) for the given land use conditions for systems (a) through (f) listed in Part I. Each student is required to submit two CADD drawings and corresponding computations prepared solely by them. Remaining drawings can be prepared by anyone else on the team, individually or collectively with others. Each group 
is to maintain a project journal, to include documentation of phone logs, meeting minutes, weekly time sheets, etc. (project journals will be reviewed on a random basis throughout the semester).

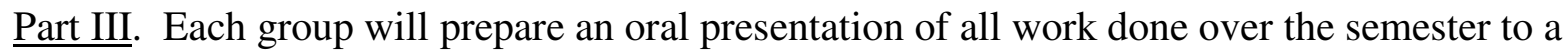
design review committee consisting of industry experts and civil engineering faculty. Also due on that day are a project brochure for hand-out at the presentation, the written report for the project, the design drawings, and the group's project journal.

Project Description. The project is located in Fairfax County near the intersection of Beulah Rd. and State Route 7. Refer to Fairfax County ordinances for descriptions of zoning districts and design standards. The 69 -acre site is a consolidation of several parcels. The area has been subdivided into one 23 -acre parcel specifically for this project. The residual 46 acres will be developed in the future.

As a condition for the rezoning, the area south of the east-west stream has been designated as a recreation area. The client has agreed to construct a soccer field, ball field and parking area, along with a trail system to this area. An access easement will be provided for the road to the recreation area. The stream crossing is preferred to be located west of the existing pond. Additionally, the client has agreed to convert the existing pond into an amenity/stormwater management pond. The structural design element of this project will be to design a vehicular bridge to cross the stream.

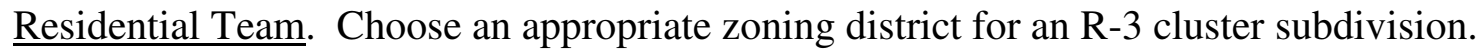

Commercial Team. Choose an appropriate zoning district for a retail site to include 220,000 sf of retail space, of which 100,000 sf is a single user anchor store. The remaining area will be ancillary retail use. The client may require 2-3 smaller ( 1 acre) pad sites for a fast-food store, and a convenience store with fuel pumps.

Industrial Team. Choose an appropriate zoning district for a 160,000 sf distribution warehouse site. A minimum of two buildings is required. Dimensions for one building are $150 \mathrm{ft}$ x $550 \mathrm{ft}$. This building will include a second floor mezzanine for office space in a single-user area of 150 $\mathrm{ft} \times 200 \mathrm{ft}$ at one end of the building. The mezzanine will be a minimum $30 \mathrm{ft}$ wide along one exterior wall. The client prefers most bays to be $50 \mathrm{ft}$ wide.

$\underline{\text { Results. }}$ To give the reader a glimpse of the amount of work involved, Figure 1 is a photoreduced copy of the site layout sheet submitted by the residential team. A typical submission package includes 20 or more similar sheets providing all of the required project details.

\section{Assessment Process}

The assessment process works as follows. The team presentations are made to a large audience, typically exceeding 100 people. All program faculty and all industry mentors assigned to the teams are automatically jury panelists. In addition, leading engineers from local companies are 




Figure 1. Typical Residential Team Plan Sheet

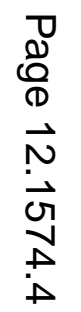


invited to attend, and as they enter the auditorium the course instructor and the department chair invite them to participate in the evaluation. The composition of the jury is similar from year to year. The core of the panel comprises the program faculty, which ensures that all professional areas are represented, and the project team professional mentors, who are very familiar with the site and tend to take a holistic view. The other members are usually senior members of land development or design firms, and representatives of local government agencies. There has been a high rate of repeat jurors, so consistency of evaluation from year to year has not been a problem.

Each juror is provided a rating instrument, with one copy for each of the team presentations to be viewed. The jurors assign numerical scores to rating categories keyed to the different design sub-areas required in the projects, e.g., transportation, water supply, etc., and also enter any comments that they deem appropriate. The numerical scores awarded by the jurors and their free-form comments are used both to assess how well students achieve the outcomes, and to diagnose potential course and program improvement needs.

Prior to 2003 the assessment process was less formal. The design jury was still impaneled as described above, but there was no formal evaluation tool. Recognizing the potential for quantifiable assessment results provided by this annual event, the program faculty sought the assistance of the university's Office of Institutional Assessment to develop an appropriate evaluation tool. The professional staff there went through a formal process of analyzing the course and program goals, identifying major assessment criteria, and developing candidate evaluation forms for faculty review. The resulting form, which has been modified slightly over the years, is presented in the Appendix.

\section{Assessment Results}

The raw data consist of the numerical scores awarded by each evaluator for each question for each team. A spreadsheet is used to compute the weighted average score for each team on each question, and the overall weighted average across all of the teams. The comments of the evaluators are also entered. Both the detailed and summary data, and the evaluator comments, are used by the program faculty to review student performance and formulate proposed program changes. The faculty have mapped the evaluation factors into ABET program outcomes a-k (Table 1) in order to track changes and trends in the level of outcome achievement. Table 2 shows the mapping and presents a summary of the assessment results over the past four years.

Over half of the evaluation factors map to a single outcome, while the rest relate to two or more of the outcomes. Some of these mappings are stronger than others. For example, the first factor, "Team narrative is clear and concise," obviously speaks directly to outcome g, effective communication. The second factor, "Team narrative is comprehensive," could measure several outcomes, but is interpreted as an indicator for outcome $\mathrm{d}$, the ability to function on multidisciplinary teams, the argument being that good teamwork is required to produce a comprehensive product. The multiple outcome factors are somewhat problematic. Under the transportation factors, for instance, the first item, "Quality of transportation analysis of project site," maps to four of the outcomes, which can make interpretation difficult. Five of the outcomes are assessed only by evaluation factors that are also used to assess other outcomes, 
Table 1. ABET Program Outcomes

Students must attain the ability to:

(a) Apply knowledge of mathematics, science and engineering

(b) Design and conduct experiments, as well as to analyze and interpret data

(c) Design a system, component, or process to meet desired needs within realistic constraints such as economic, environmental, social, political, ethical, health and safety, manufacturability, and sustainability

(d) Function on multi-disciplinary teams

(e) Identify, formulate, and solve engineering problems

(f) Understand professional and ethical responsibility

(g) Communicate effectively

(h) Understand the impact of engineering solutions in a global, economic, environmental, and societal context

(i) Recognize the need for and engage in life-long learning

(j) Have a knowledge of contemporary issues

(k) Use the techniques, skills, and modern engineering tools necessary for engineering practice.

Source: Criteria for Accrediting Engineering Programs, ABET, Inc., Baltimore, MD, Feb. 9, 2006, p. 2.

while six outcomes have one or more evaluation factors that assess a single outcome. Further, the number of evaluation factors used to assess an outcome varies from one to seven. At this writing the multiple factors for an outcome are not mathematically combined into a single outcome score. Rather, the faculty prefer to consider all of the factor scores when considering the results for a particular outcome.

The evaluation form and process will be revised in the future to provide more one-to-one mapping of evaluation results to outcomes; that is, to map few or no factors to more than one outcome. This will be accomplished by revising some of the evaluation question wordings to relate more directly to individual program outcomes. This will not reduce the overall amount of senior design evaluation information available to the faculty, but will improve the clarity and reliability of this aspect of the outcomes assessment process.

\section{Analysis and Conclusions}

It is apparent from these results that the student teams have been performing at a high level. Nearly all of the average scores are in the 4.0 to 4.5 range, on a scale of 1 to 5 . There is no score below 3.0, which would be considered "average" performance. Second, performance has tended 
Table 2. Summary of Senior Design Assessment Results

Evaluation Factors

Oral Presentation

Team narrative is clear and concise.

Team narrative is

comprehensive.

Presenters kept audience's

attention.

Presenters were very

professional.

Visual Presentation

Team uses design software

tools effectively for

supplemental engineering

computations.

Team demonstrates

competence in the use of

AutoCAD.

Team demonstrates

competence in the use of

Power Point.

Team provides enough detail so that the team solution can

be understood.

Team uses graphics

effectively to highlight correct components of solution.

\section{Transportation}

Quality of transportation analysis of project site.

Use of correct geometry in

road/street design.

Parking Design

Environment

Demonstration of environmental engineering knowledge in the overall site planning

Demonstration of environmental engineering knowledge in specific design components such as storm water drainage; sanitary sewer and water distribution system design and structures

\section{Outcomes}

g

d

g

f

k

k

g

$\mathrm{d}, \mathbf{g}$

g

b, e, h, k

a, c

c

e

b, $\mathbf{c}, \mathbf{k}$

4.18

4.26

4.28

4.11

AVG. AVG. AVG. AVG.

$\begin{array}{llll}4.29 & 4.11 & 4.55 & 4.24\end{array}$

$\begin{array}{llll}4.49 & 4.25 & 4.42 & 4.33\end{array}$

4.35

4.11

4.63

4.06

4.70

4.59

4.75

4.66

4.38

4.71

4.33

4.64

4.40

4.47

4.58

4.67

4.49

4.75

4.30

4.28

4.45

4.19

4.53

4.43

4.60

4.32

4.27

3.94

4.12

4.17

4.40

4.00

4.33

4.46

NA

NA

NA

4.09

4.30

4.17

4.33

3.86

LID features

4.18

4.26

4.28

4.11 
Table 2. (Continued)

\begin{tabular}{|c|c|c|c|c|c|}
\hline Evaluation Factors & Outcomes & $\begin{array}{l}2006 \text { WT } \\
\text { AVG. }\end{array}$ & $\begin{array}{l}2005 \text { WT } \\
\text { AVG. }\end{array}$ & $\begin{array}{l}2004 \text { WT } \\
\text { AVG. }\end{array}$ & $\begin{array}{l}2003 \text { WT } \\
\text { AVG. }\end{array}$ \\
\hline \multicolumn{6}{|l|}{ Structures } \\
\hline $\begin{array}{l}\text { Demonstration of structural } \\
\text { engineering knowledge in } \\
\text { specific design components }\end{array}$ & $c, e, k$ & 4.7 & 3.84 & 4.55 & 3.77 \\
\hline \multicolumn{6}{|l|}{ Construction } \\
\hline $\begin{array}{l}\text { Demonstration of team } \\
\text { completing construction } \\
\text { quantity "take-off" estimates }\end{array}$ & c & 4.29 & 4.32 & 3.92 & 4.04 \\
\hline $\begin{array}{l}\text { Demonstration of adherence to } \\
\text { local zoning and building } \\
\text { codes }\end{array}$ & $\mathbf{h}, \mathbf{i}, \mathbf{j}$ & 4.60 & 3.48 & 4.42 & 4.29 \\
\hline \multicolumn{6}{|l|}{ Social } \\
\hline $\begin{array}{l}\text { Demonstration of knowledge } \\
\text { of the specific social and }\end{array}$ & & & & & \\
\hline $\begin{array}{l}\text { affect the project, and } \\
\text { development of effective } \\
\text { strategies to deal with these } \\
\text { factors }\end{array}$ & $\mathbf{h}, \mathbf{i}, \mathbf{j}$ & 3.87 & 3.56 & 3.50 & 3.90 \\
\hline \multicolumn{6}{|l|}{ Economic } \\
\hline $\begin{array}{l}\text { Demonstration of knowledge } \\
\text { of the specific economic } \\
\text { considerations of the project }\end{array}$ & c & 3.93 & 3.56 & 3.91 & 3.90 \\
\hline $\begin{array}{l}\text { Team's estimate of the } \\
\text { construction costs of the } \\
\text { project. }\end{array}$ & b, c & 4.23 & 3.74 & 4.22 & 4.03 \\
\hline \multicolumn{6}{|l|}{ Project Management } \\
\hline $\begin{array}{l}\text { Team demonstrated } \\
\text { knowledge of Gantt Charts. }\end{array}$ & d, $k$ & 4.58 & 3.32 & 4.40 & 4.21 \\
\hline $\begin{array}{l}\text { The project is substantially } \\
\text { complete as of the day of the } \\
\text { presentation }\end{array}$ & f & 4.77 & 4.38 & 4.88 & NA \\
\hline
\end{tabular}

to improve over time for most of the factors. The improvement is notable for the factors related to professionalism, use of design software tools, structural engineering knowledge, construction quantity estimates, and adherence to local zoning and building codes. There has also been an overall increase in the ratings of the quality of the presentations.

Some of the significant improvements noted can be traced to faculty actions taken in response to the diagnostic results obtained in specific years. For example, the presentations were not always professional and engaging in the early years, so an instructional module on making effective presentations was added to the course. To increase structural engineering proficiency a support instructor was engaged to provide a series of lectures on this topic early in the semester. And in several topic areas the content of prerequisite courses was changed to emphasize subject matter that would be needed to complete the senior design project. For example, coverage of traffic 
signalization was increased in the required transportation engineering course, and methods of traffic impact analysis were covered earlier in the semester in the urban transportation planning course. The required hydraulics course was modified to increase coverage of topics related to open channel flow, sewer system design, and pumps. Lectures on low impact design were added to the pre-senior design required course. In this way the entire faculty has been involved in improving student performance on the capstone design project.

Finally, the jury results provide quantitative evidence that the students are achieving the program outcomes. There is no result that points to weak performance on any of the outcomes.

The civil engineering senior design course at George Mason will be undergoing some changes in the near future, motivated by a significant increase in program enrollment (170 percent over the past five years). Some of the methods presently in use do not scale very well to class sizes of 50 or more. In the coming year some of the changes include modifying how teams are formed and their specific roles in the project, and the introduction of a two-phase jury evaluation process, wherein the jurors have access to a website with the project documents approximately one week prior to the presentations. This will allow a more in-depth evaluation of the technical content of the designs, and a presentation-day evaluation of the team presentation skills. The changes will require a new set of evaluation forms, which will incorporate the valuable attributes of the present forms. Other changes to the assessment process will be made as the senior design course evolves to meet new demands caused by the changing content of the body of knowledge that must be covered in undergraduate civil engineering programs. Maintaining the ability to track program outcome achievement will be the guiding principle as these evaluation changes are designed. 


\section{Appendix: Senior Design Evaluation Form}

Thank you for being a reviewer for the senior design course in civil engineering. You will not be asked to assess any individual; rather we would like your judgment about the quality of the group work presented.

Team (please use a separate form for each team.) Commercial Residential Industrial

Please check all that apply. Are you: an alumnus an industry practitioner a faculty member a team mentor a student other

Please place a check mark in the box that represents your best judgment about the quality of this team's presentation for each statement.

\section{5=Highly Effective/Highly Proficient......... 1=Very Ineffective/Very Low Level of Proficiency \\ Communications}

\begin{tabular}{|c|c|c|c|c|c|c|}
\hline Oral Presentation & 5 & 4 & 3 & 2 & 1 & $\begin{array}{l}\text { Unable } \\
\text { to } \\
\text { Evaluate }\end{array}$ \\
\hline \multicolumn{7}{|l|}{ Team narrative is clear and concise. } \\
\hline \multicolumn{7}{|l|}{ Team narrative is comprehensive. } \\
\hline \multicolumn{7}{|l|}{ Presenters kept audience's attention. } \\
\hline \multirow{2}{*}{\multicolumn{7}{|c|}{$\begin{array}{r}\text { Presenters were very professional. } \\
\text { Visual Presentation }\end{array}$}} \\
\hline & & & & & & \\
\hline \multicolumn{7}{|l|}{$\begin{array}{l}\text { Team uses design software tools effectively } \\
\text { for supplemental engineering computations. }\end{array}$} \\
\hline \multicolumn{7}{|l|}{$\begin{array}{l}\text { Team demonstrates competence in the use of } \\
\text { AutoCAD. }\end{array}$} \\
\hline \multicolumn{7}{|l|}{$\begin{array}{l}\text { Team demonstrates competence in the use of } \\
\text { Power Point. }\end{array}$} \\
\hline \multicolumn{7}{|l|}{$\begin{array}{l}\text { Team provides enough detail so that the } \\
\text { team solution can be understood. }\end{array}$} \\
\hline $\begin{array}{l}\text { Team uses graphics effectively to highlight } \\
\text { pertinent components of solution. }\end{array}$ & & & & & & \\
\hline
\end{tabular}




\section{Problem Solving}

5=Highly Effective/Highly Proficient, 1=Very Ineffective/Very Low Level of Proficiency

\begin{tabular}{|c|c|c|c|c|c|c|}
\hline Transportation & 5 & 4 & 3 & 2 & 1 & $\begin{array}{l}\text { Unable } \\
\text { to } \\
\text { Evaluate }\end{array}$ \\
\hline \multicolumn{7}{|l|}{$\begin{array}{l}\text { Quality of transportation } \\
\text { analysis of project site }\end{array}$} \\
\hline \multicolumn{7}{|l|}{$\begin{array}{l}\text { Use of correct geometry in } \\
\mathrm{road} / \mathrm{street} \text { design }\end{array}$} \\
\hline \multicolumn{7}{|l|}{ Parking design } \\
\hline \multicolumn{7}{|l|}{ Environment } \\
\hline \multicolumn{7}{|l|}{$\begin{array}{l}\text { Demonstration of } \\
\text { environmental engineering } \\
\text { knowledge in the overall site } \\
\text { planning }\end{array}$} \\
\hline \multicolumn{7}{|l|}{$\begin{array}{l}\text { Demonstration of } \\
\text { environmental engineering } \\
\text { knowledge in specific design } \\
\text { components such as storm } \\
\text { water drainage; sanitary } \\
\text { sewer and water distribution } \\
\text { system design and structures }\end{array}$} \\
\hline \multicolumn{7}{|l|}{ Structures } \\
\hline \multicolumn{7}{|l|}{$\begin{array}{l}\text { Demonstration of structural } \\
\text { engineering knowledge in } \\
\text { specific design components }\end{array}$} \\
\hline \multicolumn{7}{|l|}{ Construction } \\
\hline \multicolumn{7}{|l|}{$\begin{array}{l}\text { Demonstration of team } \\
\text { completing construction } \\
\text { quantity "take-off" estimates }\end{array}$} \\
\hline $\begin{array}{l}\text { Demonstration of adherence } \\
\text { to local zoning and building } \\
\text { codes }\end{array}$ & & & & & & \\
\hline
\end{tabular}




\section{Social and Economic Considerations}

5=Highly Effective/Highly Proficient, 1=Very Ineffective/Very Low Level of Proficiency

\begin{tabular}{|l|l|l|l|l|l|l|}
\hline \multicolumn{1}{|c|}{ Social } & 5 & 4 & 3 & 2 & 1 & $\begin{array}{c}\text { Unable } \\
\text { to } \\
\text { Evaluate }\end{array}$ \\
\hline $\begin{array}{l}\text { Demonstration of } \\
\text { knowledge of the specific } \\
\text { social and political factors } \\
\text { that would affect the } \\
\text { project, and development } \\
\text { of effective strategies to } \\
\text { deal with these factors }\end{array}$ & & & & & & \\
\hline \multicolumn{1}{|c|}{ Economic } & & & & & & \\
\hline $\begin{array}{l}\text { Demonstration of } \\
\text { knowledge of the specific } \\
\text { economic considerations of } \\
\text { the project }\end{array}$ & & & & & & \\
\hline $\begin{array}{l}\text { Team's estimate of the } \\
\text { construction costs of the } \\
\text { project }\end{array}$ & & & & & & \\
\hline
\end{tabular}

\section{Project Management}

\begin{tabular}{|l|l|l|l|l|l|l|}
\hline & 5 & 4 & 3 & 2 & 1 & $\begin{array}{c}\text { Unable } \\
\text { to } \\
\text { Evaluate }\end{array}$ \\
\hline $\begin{array}{l}\text { Team demonstrated } \\
\text { knowledge of Gantt Charts }\end{array}$ & & & & & & \\
\hline $\begin{array}{l}\text { The project is substantially } \\
\text { complete as of the day of } \\
\text { the presentation }\end{array}$ & & & & & & \\
\hline
\end{tabular}

Please use the other side of this page for comments. Thank you. 